\title{
COMPARISON OF BACTERIAL CELLULOSE PRODUCTION BY KOMAGATAEIBACTER INTERMEDIUS STRAIN USING LAVANDULA ANGUSTIFOLIA, ROSA CANINA AND TILIA CORDATA PLANTS AS LOW-COST MEDIA
}

\author{
NERMIN HANDE AVCIOGLU, ${ }^{*}$ CANSU SEVIM, ${ }^{*}$ ELIF NAZ ALVER, ${ }^{* *}$ \\ SEBNEM DONMEZ* and ISIL SEYIS BILKAY* \\ *Hacettepe University, Faculty of Science, Biology Department, Biotechnology Section, \\ Beytepe, 06800, Ankara, Turkey \\ ${ }^{* *}$ Gazi University, Faculty of Science, Biology Department, Zoology Section, \\ Yenimahalle, 06560, Ankara, Turkey \\ ¿ Corresponding author: N. H. Avcioglu, hurkmez@hacettepe.edu.tr
}

Received July 25, 2021

\begin{abstract}
In this study, the effects of Lavandula angustifolia, Tilia cordata and Rosa canina on cellulose production by Komagataeibacter intermedius strain were investigated. T. cordata was found as the most effective plant (10.64 g/L $\mathrm{BC}$ ), under the following optimized conditions: $50 \mathrm{~g} / \mathrm{L}$ plant amount, $8 \%$ lactose, $15 \%$ inoculum amount at $\mathrm{pH}=6.0$. Total phenolic contents of $L$. angustifolia $(55.42 \mathrm{mg} / \mathrm{g}), R$. canina $(16.54 \mathrm{mg} / \mathrm{g})$ and $T$. cordata $(60.03 \mathrm{mg} / \mathrm{g})$, and total protein amounts of L. angustifolia $(7.89 \mathrm{~g} / \mathrm{L}), R$. canina $(3.54 \mathrm{~g} / \mathrm{L})$ and $T$. cordata $(5.13 \mathrm{~g} / \mathrm{L})$ were analyzed. It has been established that phenolic and protein substances contribute significantly to cellulose formation. Physicochemical analysis showed that all the peaks obtained from FTIR analysis are distinguishable for BC and pellicles show high thermal stability. This research is the first report on the usage of L. angustifolia, R. canina and T. cordata plants as lowcost substrates in $\mathrm{BC}$ production with high yields.
\end{abstract}

Keywords: bacterial cellulose (BC), Komagataeibacter intermedius, Lavandula angustifolia, Tilia cordata, Rosa canina, physicochemical characterization

\section{INTRODUCTION}

Cellulose, an important raw material of paper industry, can be obtained by purification of plants and plant extracts, as well as produced by many microorganisms. ${ }^{1,2}$ Due to its thermal, optical and mechanical properties, cellulose produced by Protista, Fungi and Bacteria started to be used instead of the plant-based one in different industrial areas. ${ }^{3}$ Unlike plant cellulose, BC does not contain lignin, hemicelluloses and other contaminants normally found in the plant structure, and can be obtained purely from the culture media. ${ }^{3,4}$ On the other hand, in order to obtain pure cellulose from plant-based sources, energy and chemicals are used, and mechanical purification processes are carried out, which have negative impacts on the environment. Furthermore, these processes significantly affect production costs, as well as change the functional structure of cellulose and limit its use in industrial areas. ${ }^{5}$ Since BC can be obtained pure from its culture media, it is very important to increase the production of $\mathrm{BC}$, which is an environmentally friendly and renewable nanomaterial, without involving any purification processes.

$\mathrm{BC}$ has a fine fibrillar structure, with a diameter of 25-100 nm, being 100 times thinner than plant cellulose. ${ }^{6,7}$ Although bacterial cellulose has a similar chemical structure to plant cellulose, its use has increased in the industrial field in recent years due to its physicochemical and mechanical properties, such as low toxicity, conformability, ${ }^{10}$ nanometer range of its crosssectional dimension, ${ }^{11}$ porosity, elongation, mechanical strength, large surface area, ${ }^{12}$ biocompatibility, ${ }^{13}$ high liquid loading capacity ${ }^{14}$ and excellent biological affinity. ${ }^{10}$ Studies are 
predominantly focused on the safety usage of $\mathrm{BC}$ in different areas and it is categorized under materials that have been "generally recognized as safe" (GRAS) by the US Food and Drug Administration (FDA). ${ }^{15}$ Also, BC can be used in nanotechnological applications, ${ }^{14}$ mining, refinery ${ }^{16}$ industries, as well as in wound dressings for damaged skin, ${ }^{17,18}$ scaffold for tissue engineering of cartilages and bones, ${ }^{19}$ dental implants ${ }^{20}$ vascular grafts, ${ }^{21}$ catheter covering dressing, ${ }^{21}$ artificial blood vessels ${ }^{22}$ and drug delivery. ${ }^{14,23}$

$\mathrm{BC}$ is formed in the air-liquid interface area of the culture medium as an extracellular insoluble polysaccharide by many microorganisms, especially by acetic acid bacteria. ${ }^{8,18,24-26}$ Some microorganisms known as cellulose producers include Acetobacter sp., ${ }^{21,27}$ Achromobacter sp. ${ }^{28,9}$ Pseudomonas sp., ${ }^{25,29}$ Azotobacter sp..$^{22}$ Sarcina $s p .{ }^{16} \quad$ Agrobacterium $s p .,{ }^{30,31}$ Komagataeibacter $s p .{ }^{10,32}$ Rhodobacter sp., ${ }^{9}$ Salmonella sp.,${ }^{19,31}$ Aerobacter sp.,${ }^{8,28}$ Alcaligenes sp. ${ }^{30,25}$ Zoogloea $^{33}$ and Medusomyces gisevii. ${ }^{34}$ Based on the literature, the Komagataeibacter genus attracts attention among celluloseproducing microorganisms due to its ability to produce higher amounts of cellulose. ${ }^{2}$ Accordingly, cellulose production in different culture media using $K$. hansenii, ${ }^{29} K$. saccharivorans, ${ }^{18}$ K. intermedius ${ }^{5}$ and $K$. xylinus ${ }^{35}$ have been studied in the literature.

Hestrin-Schramm broth is often used as a commercial medium for $\mathrm{BC}$ production in the literature. Because of the chemicals (glucose, peptone, yeast extract, $\mathrm{Na}_{2} \mathrm{HPO}_{4}$ and citric acid) in its content, the cost of cellulose production gets to be quite high when compared to low-cost media. ${ }^{36}$ For this reason, studies have focused on obtaining pure cellulose with low cost and high efficiency. In the literature, soya bean whey, ${ }^{10}$ citrus peel and pomace, ${ }^{37}$ molasses, ${ }^{1,38,39}$ pine apple, pomegranate, muskmelon, watermelon, tomato, orange juice, coconut water, ${ }^{19}$ crude glycerol, ${ }^{26}$ lemon peel, mandarin peel, orange peel, grape peel, ${ }^{29}$ rotten fruits and milk whey, ${ }^{20}$ glycerol remaining from biodiesel production and grape bagasse ${ }^{8}$ rice wine distillery wastewater, ${ }^{40}$ pecan nutshell, ${ }^{3}$ dry olive mill residue, ${ }^{24}$ pineapple waste and pawpaw waste, ${ }^{27}$ tobacco waste, ${ }^{41}$ cashew tree residue, ${ }^{32}$ tomato juice and cane molasses, ${ }^{12}$ distillery effluent, ${ }^{42}$ maple syrup, ${ }^{43}$ alcohol and dairy industry by product thin stillage, ${ }^{14}$ green tea, ${ }^{9}$ and black tea ${ }^{15}$ have been reported as low-cost substrates for cellulose production.

In this context, the main objective of this study was to produce cellulose using $L$. angustifolia, $T$. cordata and $R$. canina plants as low-cost alternative media to the Hestrin-Schram broth, which have not been reported for bacterial cellulose production before in the literature. With the use of Komagataeibacter intermedius strain as a cellulose producer, cellulose production was optimized in order to determine the most effective plant in cellulose production. In addition, the reusability of plant waste and the cost effectiveness of these culture media were also examined. Physicochemical and morphological characterization of the obtained cellulose was performed by FIB-SEM (scanning electron microscopy), Thermogravimetric Analysis (TGA) and Fourier Transform Infrared (FT-IR) Spectrometry.

\section{EXPERIMENTAL}

\section{Bacterial strain and pre-cultivation}

Komagataeibacter intermedius strain obtained from Hacettepe University Biotechnology Department Culture Collection Laboratory was used in this study. For pre-cultivation, the bacterial strain was inoculated into Hestrin-Schramm (HS) broth (containing in $\mathrm{g} / \mathrm{L}$ : 20 glucose, 5 peptone, 5 yeast extract, $2.7 \mathrm{Na}_{2} \mathrm{HPO}_{4}$, 1.15 citric acid $)^{24}$ and incubated at $30{ }^{\circ} \mathrm{C}$, for $72 \mathrm{~h}$ in a static incubator (MCI 120; Mipro, Ankara, Turkey).

\section{Low-cost substrates for BC production}

$T$. cordata, $L$. angustifolia and $R$. canina plants were brewed separately in $1 \mathrm{~L}$ of boiled distilled water for $5 \mathrm{~min}$ and glucose was added at a concentration of $40 \mathrm{~g} / \mathrm{L}$. The $\mathrm{pH}$ was adjusted to 6.0. The culture media were sterilized at $110{ }^{\circ} \mathrm{C}$ for $30 \mathrm{~min}$. Then, the concentration of $K$. intermedius strain was adjusted to $\mathrm{OD}_{600 \mathrm{~nm}}=0.20-0.25$ and $10 \%(\mathrm{v} / \mathrm{v})$ of bacterial culture was inoculated into the culture media. Incubation was carried out at $30{ }^{\circ} \mathrm{C}$ for 7 days in a static incubator (MCI 120, Mipro, Ankara, Turkey).

Optimization of physicochemical parameters for enhanced $\mathrm{BC}$ production

$T$. cordata, L. angustifolia and $R$. canina plants were used in the culture media in order to select the most effective one in bacterial cellulose production with low cost. Accordingly, different parameters, such as carbon sources (glucose, sucrose, maltose, and lactose), with different concentrations of the selected carbon source $(2 \%-10 \%), \mathrm{pH}(3-8)$, plant amount $(0.25 \%-6 \%)$ and inoculum amount $(2.5 \%-30 \%)$, were examined. 
Total reducing sugar, phenolic content and protein amount in low-cost media

The amount of reducing sugar and protein amount in the low-cost culture media (both un-inoculated and inoculated) were assayed using DNS (dinitrosalic acid) and Lowry methods, respectively. ${ }^{44,45}$ Total phenolic content was determined based on the colorimetric method described by Singleton et al. ${ }^{46}$ Glucose, bovine serum albumin and gallic acid were used as standards in DNS, Lowry and total phenolic content calculations, respectively.

\section{BC purification and quantification}

Cellulose membranes were harvested from the upper surface of the culture media and centrifuged at $2993 \mathrm{x} \mathrm{g}$ for $15 \mathrm{~min}$ (Eppendorf Centrifuge 5417R, Hamburg, Germany). In order to eliminate the entrapped cells, the cellulose membranes were washed with distilled water and $1 \mathrm{M} \mathrm{NaOH}$ solution at $80{ }^{\circ} \mathrm{C}$ for 1 hours, respectively. ${ }^{47}$ Following, BC was washed with distilled water again until it reached a neutral $\mathrm{pH}$. Lastly, purified BC was dried at $30{ }^{\circ} \mathrm{C}$ for $24 \mathrm{~h}$. The dry weight, productivity rate and yield were determined. The productivity rate and yield were calculated as follows: ${ }^{48,16}$

Productivity rate $\left(\mathrm{gL}^{-1} \mathrm{~h}^{-1}\right)=[$ Dry weight $(\mathrm{g})$ / (Reaction volume (L) x Time (h)]

Yield $(\%)=[$ Dry weight $(\mathrm{g}) /$ Carbon concentration (g)) $\mathrm{x} 100]$

\section{Water holding capacity (WHC)}

To evaluate the amount of water held by the cellulose fibers, BC was centrifuged at $2993 \mathrm{x} \mathrm{g}$ for 15 min (Eppendorf Centrifuge 5417R, Hamburg, Germany) and the samples were weighed. Then, the BC membranes were dried until reaching a constant weight at $30{ }^{\circ} \mathrm{C}$ for $24 \mathrm{~h}$. The WHC was calculated as follows: ${ }^{49}$

$$
\text { WHC }(\%)=\left[\left(\mathrm{W}_{\text {wet }}-\mathrm{W}_{\mathrm{dry}}\right) / \mathrm{W}_{\text {wet }}\right] \times 100 \%
$$

\section{Investigation of waste usage on $\mathrm{BC}$ production}

To determine the re-usability of $T$. cordata, $L$. angustifolia and $R$. canina plant waste (brewed plants were used as waste) in BC production as culture media, the plant wastes were brewed again. The preculture was inoculated into the media $\left(\mathrm{OD}_{600 \mathrm{~nm}}=0.20\right.$ 0.25 ) and incubation was performed at $30{ }^{\circ} \mathrm{C}$ for 7 days in a static incubator (MCI 120, Mipro, Ankara, Turkey).

Economic evaluation of BC production in standard, optimized and non-optimized media

BC was produced in Hestrin-Schramm broth, as well as in optimized and non-optimized media containing $T$. cordata, L. angustifolia and $R$. canina plants, separately. According to the results, the average cost, cost reduction percent and increase in $\mathrm{BC}$ production were determined.

\section{Physicochemical and morphological characterization}

BC membranes were characterized in terms of membrane morphology, thermal stability and functional groups and their interactions by using FIBSEM (Scanning Electron Microscopy) (FIB-SEM GAIA3, Tescan, Czech Republic), operating at 30kV and magnification of $30 \mathrm{kx}$ and $60 \mathrm{kx}$, Thermogravimetric Analysis (TGA) (TA Instruments Q600 SDT, USA) under $\mathrm{N}_{2}$ atmosphere over a dynamic temperature range of $30-700{ }^{\circ} \mathrm{C}$, and Fourier Transform Infrared (FT-IR) Spectroscopy (Thermo Fisher Nicolet IS50 Spectrophotometer, USA); FT-IR spectra were collected over the range from $4000 \mathrm{~cm}^{-1}$ to $450 \mathrm{~cm}^{-1}$ in transmittance mode with an accumulation of 16 scans.

\section{RESULTS AND DISCUSSION}

Optimization of physicochemical parameters for enhanced BC production with low-cost substrates

The physicochemical properties and the amount of obtained $\mathrm{BC}$ as a secondary metabolite are affected by $\mathrm{C}$ and $\mathrm{N}$ sources, $\mathrm{P}, \mathrm{S}, \mathrm{Mg}$, salts and the concentrations of these substances in the culture media. Furthermore, the cultivation conditions, such as the microorganism type, $\mathrm{pH}$, temperature, incubation time, agitation speed, aerobic conditions and inoculum amount also have a role in BC production..$^{3,4,10,22,26,50}$ The Hestrin-Schramm broth used in BC production appears as an expensive medium due to the glucose, yeast extract, peptone and minerals in its content. $^{19,32,30}$ Accordingly, the high price of cellulose production is primarily due to the medium content, which significantly hinders its usage in different areas. ${ }^{4}$ Therefore, it is of interest to investigate alternative media using low-cost substrates. In this context, the use of low-cost carbon and nitrogen sources in cellulose production is very important for obtaining cellulose with high efficiency. ${ }^{6}$

In this study, various plants were used as lowcost substrates for $\mathrm{BC}$ production due to their valuable ingredients, such as vitamins, flavonoids, carotenoids, polyphenols, reduced sugar, organic acids and essential fatty acids. ${ }^{51,52}$ Accordingly, $T$. cordata, L. angustifolia and $R$. canina plants were used as not only nitrogen or carbon sources, but also as valuable substrates for cellulose production. It was observed that the highest cellulose production was obtained with the concentrations of $25 \mathrm{~g} / \mathrm{L} \mathrm{L}$. angustifolia $(2.875$ $\mathrm{g} / \mathrm{L} \quad \mathrm{BC}, \quad 7.18 \%$ yield, $\quad 1.71 \times 10^{-2} \mathrm{gL}^{-1} \mathrm{~h}^{-1}$ 
productivity rate) and $R$. canina $(4.7 \mathrm{~g} / \mathrm{L} \mathrm{BC}$, $11.75 \%$ yield, $2.79 \times 10^{-2} \mathrm{gL}^{-1} \mathrm{~h}^{-1}$ productivity rate) and $50 \mathrm{~g} / \mathrm{L} T$. cordata $(2.32 \mathrm{~g} / \mathrm{L} \mathrm{BC}, 5.81 \%$ yield, $1.38 \times 10^{-2} \mathrm{gL}^{-1} \mathrm{~h}^{-1}$ productivity rate). Additionally, it was also determined that $\mathrm{BC}$ production decreased above the optimal level of the plant amount used in BC production (Fig. 1a, Fig. 2a and Fig. 3a).

Plants, plant extracts and various bioactive compounds, such as chloronic, ferulic, cinnamic, rosmarinic acids obtained from plants, are increasingly used in the pharmaceutical, cosmetics and food industries. ${ }^{53}$ These bioactive compounds are known as phenolic acids, flavonoids, carotenoids, vitamin A, vitamin $\mathrm{E}$ and vitamin $\mathrm{C}$, and they are synthesized by the plants as secondary metabolites. Among them, phenolic acids have highly active antioxidant properties ${ }^{54}$ and are essential for the growth of plants, as well as for protecting them from unfavorable environmental conditions, drought, UV radiation, infections and physical injury. ${ }^{55}$ Polyphenolic substances include flavonoids, anthocyanins, procyanidins, catechin, quercetin, phenolic acids, such as gallic and ellagic acids, kaempferol, apigenin and resveratrol. ${ }^{56}$ In this study, total phenolic contents of Lavandula angustifolia, Rosa canina and Tilia cordata plants were calculated as $55.42 \mathrm{mg} / \mathrm{g}, \quad 16.54 \mathrm{mg} / \mathrm{g}$ and $60.03 \mathrm{mg} / \mathrm{g}$, respectively (data not shown). During the cellulose production process, $7.3 \%, 11.9 \%$ and $32.6 \%$ of the total phenolics were used by $K$. intermedius strain from $L$. angustifolia, $R$. canina and $T$. cordata plants under optimal conditions, respectively (data not shown). Lima et al. $(2017)^{57}$ determined that phenolic substances naturally contained in sisal juice increased BC production by inhibiting organic acid accumulation in the culture media. Similarly, in this study, it was observed that BC production primarily was achieved by using the phenolic compounds in the plants and the highest $\mathrm{BC}$ production $(10.6 \mathrm{~g} / \mathrm{L} \mathrm{BC})$ was obtained from $T$. cordata plant (containing $60.03 \mathrm{mg} / \mathrm{g}$ phenolics), which is recognized in the USA by Food and Drug Administration as a safe product ${ }^{58}$ (Fig. 3).

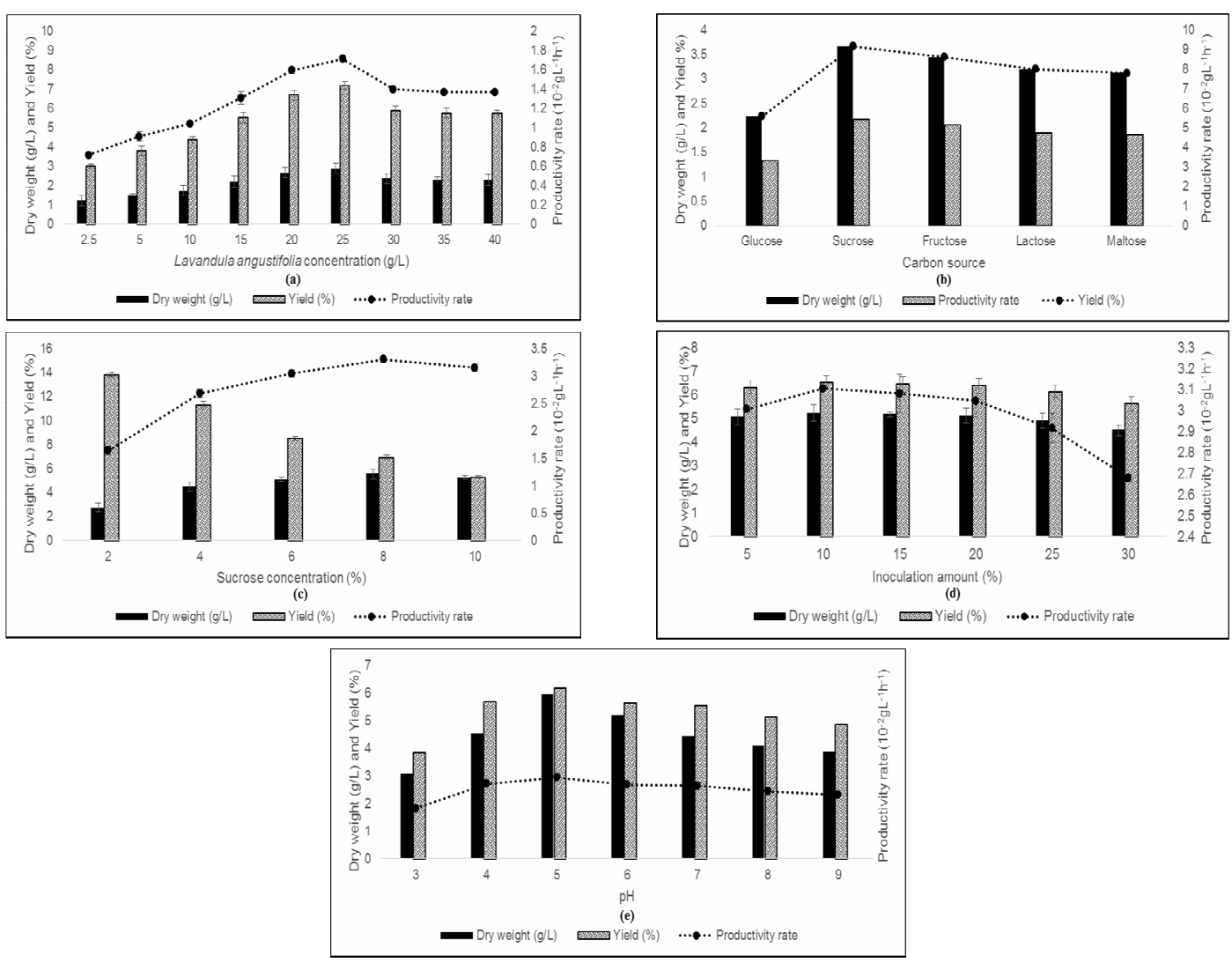

Figure 1: Effect of optimization parameters on cellulose production with Lavandula angustifolia; (a) Plant concentration; (b) Carbon source; (c) Sucrose concentration;

(d) Inoculation amount; (e) $\mathrm{pH}$ 


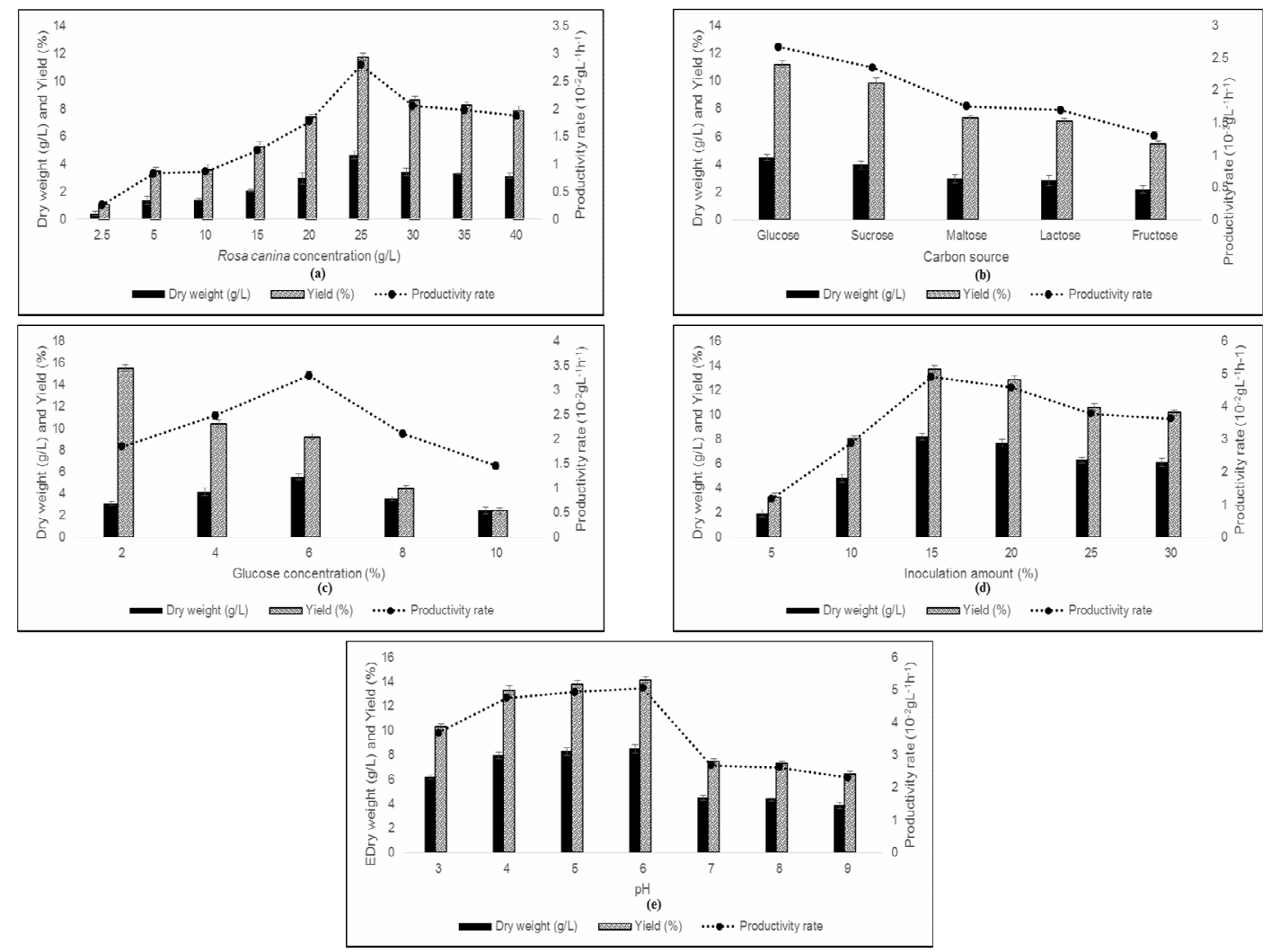

Figure 2: Effect of optimization parameters on cellulose production with Rosa canina; (a) Plant concentration; (b) Carbon source; (c) Sucrose concentration; (d) Inoculation amount; (e) pH

Also, R. canina contains important phytochemicals, such as ascorbic acid, phenolics, carotenoids, sugars, organic acids, and tocopherols, as well as mineral substances such as calcium, potassium, phosphorus, and fatty acids. ${ }^{52,56}$ In the literature, it has been reported that the presence of ascorbic acid in the culture media reduces the formation of gluconic acid due to its antioxidant properties. ${ }^{17}$ Therefore, the data obtained from this research clearly show that not only the phenolic compounds in $R$. canina, but also ascorbic acid contributes to the formation of BC (8.5 g/L BC under optimized conditions) by $K$. intermedius strain (Fig. 2).

In the literature, it has been reported that the optimal use of nitrogen source increases BC production, while the addition of an extra nitrogen source causes the formation of biomass, but decreases cellulose production. Since the use of yeast extract and peptone as nitrogen sources in the culture media causes additional costs, it is very important to investigate cheap nitrogen sources to be used in BC production., ${ }^{422}$ According to the literature, the nitrogen source is an inevitable factor in the production of $\mathrm{BC}$.
When there was only a carbon source in the culture media, BC production was not observed, while $\mathrm{BC}$ formation was observed when nitrogen sources, such as yeast extract or bacto-peptone, were added. ${ }^{59}$ In a study, it was reported that the lack of nitrogen caused a $30 \%$ reduction in $\mathrm{BC}$ production by $G$. intermedius. ${ }^{39}$ Therefore, yeast extract, casein hydrolysate, ammonium sulfate, peptone, sodium glutamate, glycine and tea substrate have been used as nitrogen sources in BC production. ${ }^{9}$ Although the culture medium used in this study did not contain any additional nitrogen sources or minerals, high levels of cellulose were obtained from all of the plants used (Fig. 1, Fig. 2 and Fig. 3). To evaluate the protein amounts of plants, Lowry's method ${ }^{45}$ was used and $7.89 \mathrm{~g} / \mathrm{L}, 3.54 \mathrm{~g} / \mathrm{L}$ and $5.13 \mathrm{~g} / \mathrm{L}$ of protein were determined for $L$. angustifolia, $R$. canina and $T$. cordata, respectively. During the BC production process, $9.8 \%, 20.4 \%$ and $57.6 \%$ of these protein contents were used, respectively (data not shown). Therefore, it can be concluded that the required nitrogen source for cellulose production was used from the plants by $K$. intermedius strain. Additionally, the decrease in 
the amount of cellulose as the plant amount increases can be explained by the fact that the increase in the amount of nitrogen in BC production inhibits the cellulose production above the optimal level (Fig. 1a, Fig. 2a and Fig. 3a).

Microorganisms need a carbon source for their growth and metabolic activities. An insufficient amount of carbon sources in the culture media limits BC production. ${ }^{21}$ It has been reported that 5 and 6 carbon compounds can be used in the production of $\mathrm{BC}{ }^{38} \mathrm{BC}$ production is carried out as a result of the regulation of enzymes by the Emden-Meyerhof-Parnas (EMP) and tricarboxylic acid (TCA) pathways. $^{20}$ Unlike other carbon sources, glucose is stated to be the primary carbon source in BC production in the literature, as it directly participates in the production pathway. ${ }^{20,38,60}$ It is also known that glucose is not only an energy source in BC synthesis, but also an important precursor involved in cellulose polymerization. ${ }^{50}$ Since glucose is the precursor of cellulose synthesis, all compounds that can be converted to glucose have the ability to produce
BC. ${ }^{2}$ However, it is known that the use of increasing amounts of glucose causes the accumulation of gluconic acid in the culture media and drops the $\mathrm{pH}$, having a negative effect on the production efficiency. ${ }^{20,40}$ Accordingly, the effects of different carbon sources, such as sucrose, glucose, lactose and fructose on cellulose production were also examined in this study. According to the results, the most effective carbon sources in $\mathrm{BC}$ production were found to be sucrose (3.66 g/L BC), glucose (4.48 g/L BC) and lactose $(5.91 \mathrm{~g} / \mathrm{L} \mathrm{BC})$ from $L$. angustifolia, $R$. canina and $T$. cordata, respectively (Figs. 1b, 2b and $3 \mathrm{~b}$ ). Additionally, the total reduced sugar contents of these plants were measured by the DNS method $^{45}$ and $0.11 \mathrm{~g} / \mathrm{L}, 0.03 \mathrm{~g} / \mathrm{L}$ and 0.054 $\mathrm{g} / \mathrm{L}$ total reduced sugar were determined, and $33.6 \%, 60 \%$ and $88.9 \%$ of these sugar contents were used with the addition of the optimal carbon source in the culture media under optimal conditions (data not shown) by $K$. intermedius strain from $L$. angustifolia, $R$. canina and $T$. cordata plants, respectively.

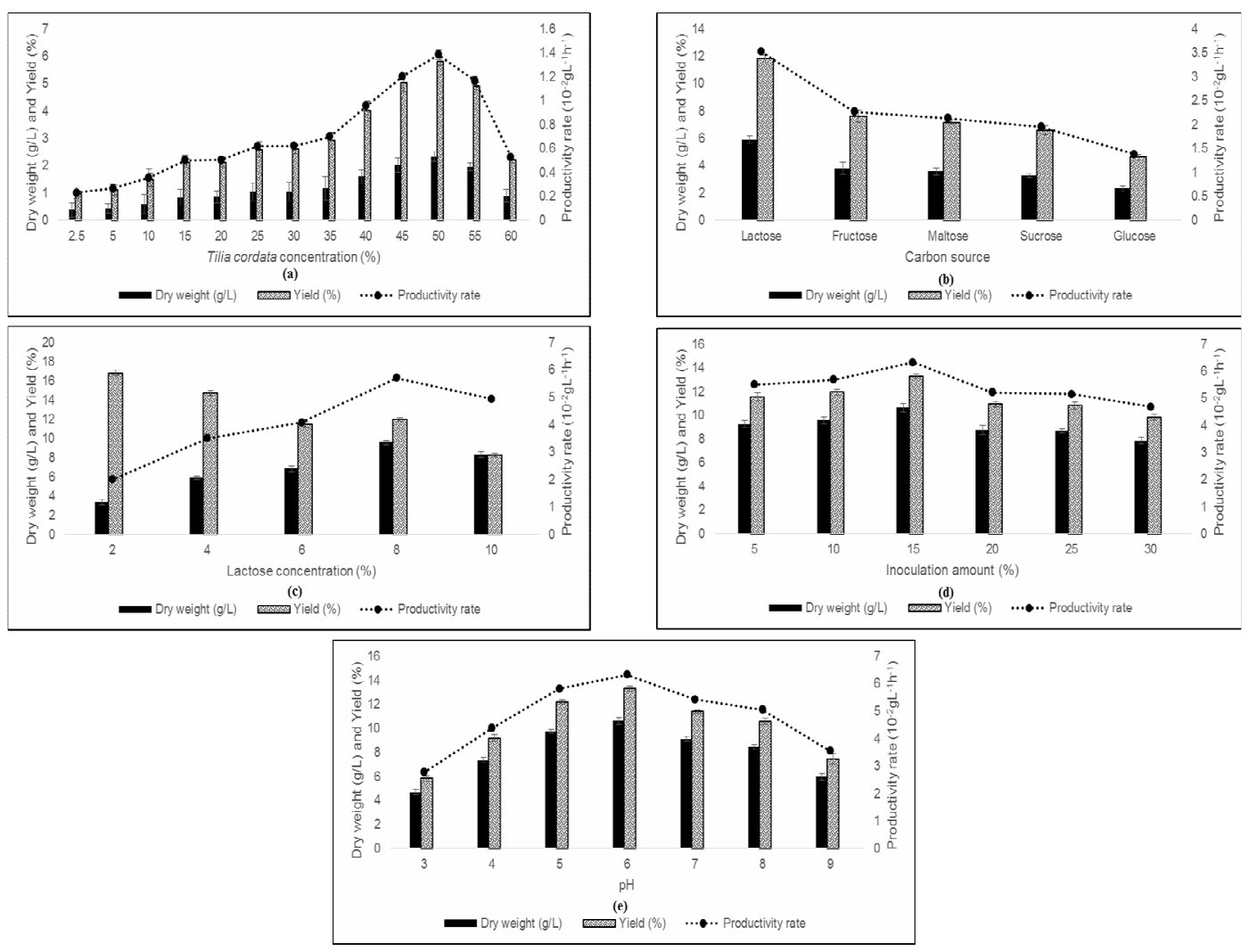

Figure 3: Effect of optimization parameters on cellulose production with Tilia cordata; (a) Plant concentration; (b) Carbon source; (c) Sucrose concentration; (d) Inoculation amount; (e) $\mathrm{pH}$ 
According to the literature, different species of microorganisms in the same genus have different metabolic preferences. ${ }^{48}$ However, in this study, it was found that the most effective carbon source changes depending on the low-cost substrate used in the culture media (Fig. 1b, Fig. 2b and Fig. 3b). Since carbon sources have different molecular weights, chemical structure, and bioavailability, different $\mathrm{BC}$ production rates and structural properties may result. ${ }^{2}$ In the literature, 1.58-2.35 $\mathrm{g} / \mathrm{L} \mathrm{BC}$ was produced using sucrose as a carbon source by Gluconacetobacter sp. ${ }^{60} 1.6 \mathrm{~g} / \mathrm{L}$ BC by $K$. sucrofermentans and $0.040 \mathrm{~g} / \mathrm{L}$ BC was produced by Komagataeibacter W1 when lactose was used. $^{2,40}$

In this study, $8 \%$ sucrose $(5.55 \mathrm{~g} / \mathrm{L} \mathrm{BC}, 6.93 \%$ yield, $3.3 \times 10^{-2} \mathrm{gL}^{-1} \mathrm{~h}^{-1}$ productivity rate), $6 \%$ glucose $\left(5.53 \mathrm{~g} / \mathrm{L} \mathrm{BC}, 9.22 \%, 3.29 \times 10^{-2} \mathrm{gL}^{-1} \mathrm{~h}^{-1}\right.$ productivity rate) and $8 \%$ lactose $(9.58 \mathrm{~g} / \mathrm{L} \mathrm{BC}$, $11.98 \%, 5.7 \times 10^{-2} \mathrm{gL}^{-1} \mathrm{~h}^{-1}$ productivity rate) were found as optimal carbon concentrations for $L$. angustifolia, T. cordata and $R$. canina plants, respectively. It was also observed that the amount of $\mathrm{BC}$ produced decreased with the increase in carbon concentration above the optimal level (Fig. 1c, Fig. 2c and Fig. 3c). Similar to our study, it has been stated that as the amount of carbon source increases, the use of the carbon source by the microorganism decreases. ${ }^{24,61}$ The primary reason is the presence of excess sugar in the culture media, which causes the formation of more metabolic products and these metabolic products inhibit $\mathrm{BC}$ formation. It is also thought that the unequal rate of nutrient transportation and their utilization may result in production inhibition. $^{15,21}$ Similarly, in a study, it was observed that $\mathrm{BC}$ production increased up to $2 \%$ sucrose concentration, but decreased when the amount of sucrose was increased above this concentration. ${ }^{22}$ In another study, it was stated that when the amount of glucose increases in the culture media, the amount of cellulose decreases, and at the same time, the presence of a small amount of glucose in the culture media prevents the growth of acetic acid bacteria and causes a decrease in $\mathrm{BC}$ production. ${ }^{15}$

The optimal inoculum amounts for the highest cellulose production were found as $10 \%(5.21 \mathrm{~g} / \mathrm{L}$ $\mathrm{BC}, 6.52 \%, 3.1 \times 10^{-2} \mathrm{gL}^{-1} \mathrm{~h}^{-1}$ productivity rate), $15 \%(8.23 \mathrm{~g} / \mathrm{L} \mathrm{BC}, 13.72 \%)$ and $15 \%(10.65 \mathrm{~g} / \mathrm{L}$ $\mathrm{BC}, 13.31 \%, 6.33 \times 10^{-2} \mathrm{gL}^{-1} \mathrm{~h}^{-1}$ productivity rate) by $K$. intermedius strain with $L$. angustifolia, $R$. canina and $T$. cordata plants, respectively. It was also found that an inoculum amount above the optimal value had a negative effect on cellulose formation (Fig. 1d, Fig. 2d and Fig. 3d). It has been found in the literature that $\mathrm{BC}$ production decreases due to the increase in inoculum amount, as there will be a competition among microorganisms for nutrient use. ${ }^{4}$ In the literature, inoculum amounts of $20 \%,{ }^{4} 10 \%{ }^{34}$ and $6 \%{ }^{42}$ were used with different bacterial strains.

When the effect of $\mathrm{pH}$ on $\mathrm{BC}$ production was examined, the most effective $\mathrm{pH}$ value in cellulose production was found as $5(5.94 \mathrm{~g} / \mathrm{L} \mathrm{BC}$, $6.18 \%$ yield, $2.94 \times 10^{-2} \mathrm{gL}^{-1} \mathrm{~h}^{-1}$ productivity rate) with $L$. angustifolia plant and the optimal $\mathrm{pH}$ value for $R$. canina and $T$. cordata was found as pH 6 (8.5 g/L BC, $14.16 \%$ yield, $5.05 \times 10^{-2} \mathrm{gL}^{-1} \mathrm{~h}^{-1}$ productivity rate and $10.64 \mathrm{~g} / \mathrm{L} \mathrm{BC}, 13.3 \%$ yield, $6.33 \times 10^{-2} \mathrm{gL}^{-1} \mathrm{~h}^{-1}$ productivity rate, respectively) (Fig. 1e, Fig. 2e and Fig. 3e). Each microorganism needs an optimal $\mathrm{pH}$ value in order to survive and grow in the culture media. ${ }^{15}$ Also, it is very important to achieve the maximum $\mathrm{BC}$ production. Similarly to our research, it has been reported that $\mathrm{BC}$ production was carried out effectively at acidic and near neutral $\mathrm{pH}$ values. ${ }^{18,50}$ Aswini et $a l .{ }^{4}$ reported that the optimal $\mathrm{pH}$ of the medium is important for the occurrence of oxidative reactions, the solubility and uptake of nutrients for $\mathrm{BC}$ production.

To sum up, T. cordata, L. angustifolia and $R$. canina plants were used as low-cost substrates for optimization of cellulose production by $K$. intermedius. The optimized conditions for cellulose production were found as $25 \mathrm{~g} / \mathrm{L}$ plant amount, $8 \%$ sucrose, $10 \%$ inoculum amount, at pH 5.0 for L. angustifolia (Fig. 1), $25 \mathrm{~g} / \mathrm{L}$ plant amount, $6 \%$ glucose, $15 \%$ inoculum amount, at pH 6.0 for Rosa canina (Fig. 2) and 50 g/L plant amount, $8 \%$ lactose, $15 \%$ inoculum amount at $\mathrm{pH}$ 6.0 for $T$. cordata (Fig. 3). Under these optimal conditions, $5.42 \mathrm{~g} / \mathrm{L} \mathrm{BC}, 8.5 \mathrm{~g} / \mathrm{L} \mathrm{BC}$ and 10.64 $\mathrm{g} / \mathrm{L} \mathrm{BC}$ were produced with $L$. angustifolia, $R$. canina and $T$. cordata plants, respectively. Based on the literature, $4.14 \mathrm{~g} / \mathrm{L} \mathrm{BC}$ was produced by Komagataeibacter $s p$. with soya bean whey, ${ }^{10}$ $3.92 \mathrm{~g} / \mathrm{L}$ BC by $K$. hansenii with fruit peels ${ }^{29}$ and $3.3 \mathrm{~g} / \mathrm{L}$ BC by $K$. medellensis with glucose as substrates. ${ }^{48}$ When comparing the data obtained in our study with the results reported in the literature, it can be concluded that high amounts of BC were produced by $K$. intermedius strain with the use of $L$. angustifolia, $R$. canina and $T$. cordata plants and the selective carbon sources, without any supplement in the culture media. Also, $R$. canina and $T$. cordata were found as 
effective substrates in cellulose production, when compared to L. angustifolia.

\section{Water holding capacity (WHC)}

WHC is defined as an important physical property for $\mathrm{BC}$ regarded as a biomaterial in industrial fields, such as the biomedical (wound dressing, drug release) and food packaging industries. ${ }^{43,62}$ The WHC of the cellulose pellicles produced from $L$. angustifolia, $R$. canina and $T$. cordata plants was found as $84.93 \%, 100 \%$ and
97.9\%, respectively. Also, the $\mathrm{WHC}$ of the $\mathrm{BC}$ pellicle obtained from HS media was analyzed and it was found as $97.4 \%$. In the literature, WHCs of BC pellicles were reported as 85.9$98.6 \%,{ }^{63} 97.6-104.4 \mathrm{~g} / \mathrm{g},{ }^{64} 99.5 \%,{ }^{65} \quad 100.09$ $102.51 \mathrm{~g} / \mathrm{g}^{66}$ and $10.1 \%-20.9 \% .^{5}$ Based on the literature, all of the $\mathrm{BC}$ pellicles obtained from this research are suitable for use in various industrial areas considering their high WHC values.

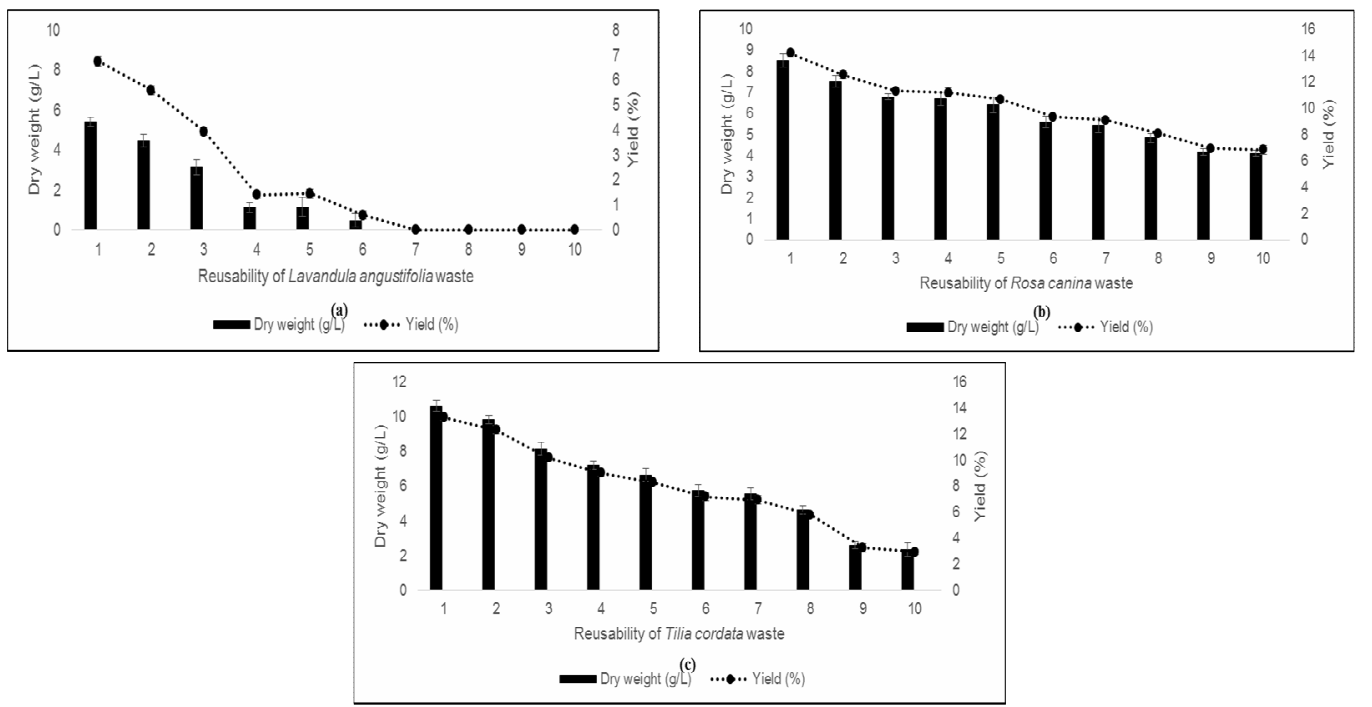

Figure 4: Reusability of plant waste in cellulose production; (a) Lavandula angustifolia; (b) Rosa canina; (c) Tilia cordata

\section{Waste usage in cellulose production}

The use of waste materials in the production of $\mathrm{BC}$ is an effective method of reducing costs, as well as for avoiding the waste disposal problem. ${ }^{11}$ In this context, the re-usability of plant wastes in $\mathrm{BC}$ production was investigated. R. canina and $T$. cordata plant wastes can be used at least ten times again in the cellulose production media and $L$. angustifolia waste can be used 6 times at most (Fig. 4). Although plant wastes were re-used 10 times, $4.11 \mathrm{~g} / \mathrm{L}$ and $2.36 \mathrm{~g} / \mathrm{L} \mathrm{BC}$ production was observed on the $10^{\text {th }}$ brew of $R$. canina and $T$. cordata, respectively (Fig. 4a and Fig. 4b). In the literature, $1.177 \mathrm{~g} / \mathrm{L} \mathrm{BC}$ was produced with wastewater, ${ }^{13} 5.7 \mathrm{~g} / \mathrm{L}$ BC with industrial waste by $K$. xylinus ${ }^{38}$ and $4.01 \mathrm{~g} / \mathrm{L}$ BC with sugarcane molasses by $K$. rhaeticus. ${ }^{55}$ In a different study, sisal waste supplemented with yeast extract and sugar was used, and the highest BC amount was found as $3.38 \mathrm{~g} / \mathrm{L}$ by $K$. hansenii. ${ }^{57}$ In our work, it is seen that the amount of $\mathrm{BC}$ obtained when using plant wastes without any supplements is quite high when compared to the values reported in the literature (Fig. 4).

Economic evaluation of $B C$ production in standard, optimized and non-optimized media

In order to reduce the production cost and to achieve high amounts of $\mathrm{BC}$, the cultivation conditions were optimized. It was observed that the $\mathrm{BC}$ amount was 4.6 times higher than that from the non-optimized medium when $T$. cordata was used. The amounts of cellulose pellicles obtained from both $L$. angustifolia and $R$. canina plants were 1.8 times higher than those obtained under non-optimized conditions. Additionally, the highest cost reduction was obtained from $R$. canina media (30\%). When the media were compared with each other, it was observed that the highest amount of cellulose was achieved from $T$. cordata media (10.6 $\mathrm{g} / \mathrm{L} \mathrm{BC})$. Also, the cellulose amounts from $T$. cordata and $R$. canina plants were 1.6 and 1.25 times higher than the 
amount obtained from HS media $(6.6 \mathrm{~g} / \mathrm{L} \mathrm{BC})$ (Table 1).

Compared to the amount of $\mathrm{BC}$ produced in HS medium, it was observed that $44.1 \%$ and $45.4 \%$ cost reduction was achieved per $\mathrm{g}$ of obtained BC with the use of Tilia cordata and Rosa canina plants, respectively. Additionally, when compared to the amount of $\mathrm{BC}$ produced in non-optimized media, $78.5 \%, 46.2 \%$ and $44.7 \%$ cost reduction per $\mathrm{g}$ of obtained $\mathrm{BC}$ was achieved with the use of optimized Tilia cordata, $L$. angustifolia and Rosa canina media, respectively (data not shown). Therefore, it was determined that $T$. cordata and $R$. canina plants can be used as alternative plant-based media in BC production with low cost and high efficiency. Similarly to our research, Revin et al. ${ }^{14}$ also produced cellulose $(6.19 \mathrm{~g} / \mathrm{L} \mathrm{BC})$ with wheat thin stillage, which was 3 times more effective than the HS medium $(2.14 \mathrm{~g} / \mathrm{L} \mathrm{BC})$ and it was observed that it is important to optimize the cultivation conditions for increasing product yield and reducing costs.

Table 1

Comparison of cellulose production in different culture media

\begin{tabular}{|c|c|c|c|c|c|c|}
\hline \multirow[b]{2}{*}{ Medium } & \multirow[b]{2}{*}{$\begin{array}{c}\text { C source } \\
(\mathrm{g} / \mathrm{L})\end{array}$} & \multirow[b]{2}{*}{ Ingredients } & \multicolumn{2}{|c|}{ BC production $(\mathrm{g} / \mathrm{L})$} & \multicolumn{2}{|c|}{ Cost } \\
\hline & & & $\begin{array}{c}\text { Non- } \\
\text { optimized }\end{array}$ & Optimized & $\begin{array}{l}\text { Total price } \\
\text { (Euro) }\end{array}$ & $\begin{array}{c}\text { Cost reduction } \\
(\%)\end{array}$ \\
\hline Hestrin-Schramm & Glucose & $\begin{array}{c}\text { Peptone } \\
\text { Yeast extract } \\
\mathrm{Na}_{2} \mathrm{HPO}_{4} \\
\text { Citric acid }\end{array}$ & 1 & 6.6 & $\sim 5.1$ & 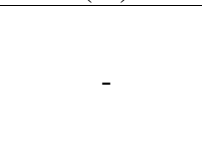 \\
\hline T. cordata & Lactose & T. cordata & 2.3 & 10.6 & $\sim 4.6$ & $\sim 10$ \\
\hline L. angustifolia & Sucrose & L. angustifolia & 2.9 & 5.4 & $\sim 4.6$ & $\sim 9.5$ \\
\hline R. canina & Glucose & R. canina & 4.7 & 8.5 & $\sim 3.6$ & $\sim 30$ \\
\hline
\end{tabular}
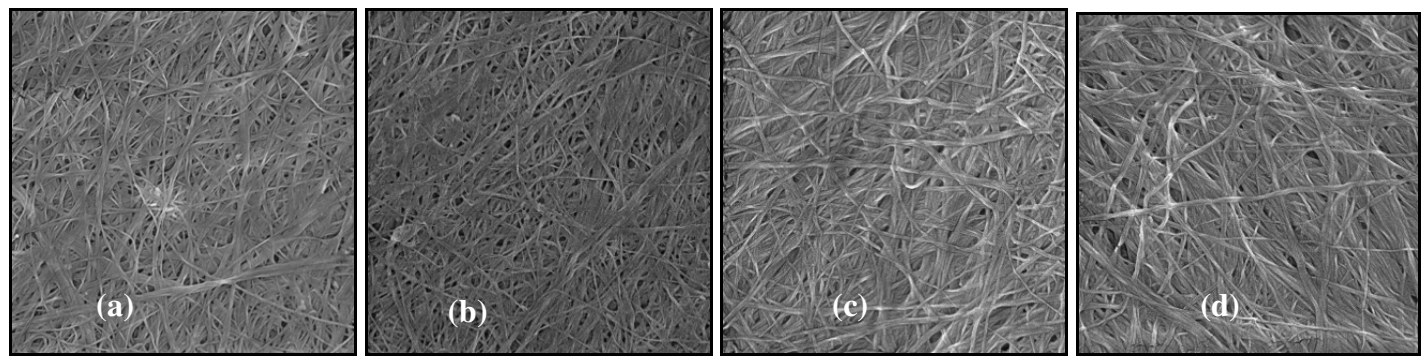

Figure 5: SEM images of bacterial cellulose; Hestrin-Schramm medium (a), Lavandula angustifolia (b), Rosa canina (c), Tilia cordata (d)

\section{Physicochemical characterization}

and

The physicochemical and morphological properties of the obtained cellulose were analyzed by FIB-SEM (scanning electron microscopy), Thermogravimetric Analysis (TGA) and Fourier Transform Infrared (FT-IR) Spectroscopy. Based on the literature, the composition of media directly affects the mechanical strength and the morphological characteristics of the obtained cellulose. ${ }^{26}$ However, when the cellulose pellicles obtained from different plants and HS medium were analyzed, it was observed that they showed homogeneous 3D network and porous structure. The $\mathrm{BC}$ fibrils were randomly organized and exhibited the typical structure of nanofibrils of $\mathrm{BC}$ in all the samples (Fig. 5).
The chemical structure and conformational properties of the obtained $\mathrm{BC}$ pellicles from the most effective plants ( $T$. cordata and $R$. canina) in cellulose production were determined by FTIR. The spectra of $\mathrm{BC}$ obtained from $T$. cordata, $R$. canina plants and HS media showed similar peaks to those reported in the literature. Based on the literature, however, the curves of the peaks may vary depending on the origin of cellulose, the fingerprint peaks directly refer to the structure of the obtained material. ${ }^{28}$ Accordingly, the broad bands at $3600-3100 \mathrm{~cm}^{-1}$ refer to $-\mathrm{OH}$ stretching vibrations of inter- and intramolecular $\mathrm{H}$ bonds, ${ }^{7,33,67}$ and the bands at $2800-2900 \mathrm{~cm}^{-1}$ are assigned to $\mathrm{C}-\mathrm{H}$ stretching. ${ }^{12,28,31}$ The band at $\sim 1640 \mathrm{~cm}^{-1}$ refers to the deformation of the absorbed $\mathrm{H}_{2} \mathrm{O}$ molecule, ${ }^{22,28,33}$ while that at 
$\sim 1300-\sim 1400 \quad \mathrm{~cm}^{-1} \quad$ corresponds $\quad \mathrm{CH}$ bending. ${ }^{12,31,33}$ Lastly, the region at $\sim 1160-600$ $\mathrm{cm}^{-1}$ refers to the carbohydrate monomers connected into a polymer, with the $\mathrm{C}-\mathrm{O}-\mathrm{C}$ bending or antisymmetric bridge stretching for the
C-O-C groups in cellulose. ${ }^{6,33}$ To sum up, all the peaks obtained from FTIR analysis are distinguishable for $\mathrm{BC}$ and the functional groups of the obtained cellulose show similar peaks to those stated in the literature (Fig. 6).

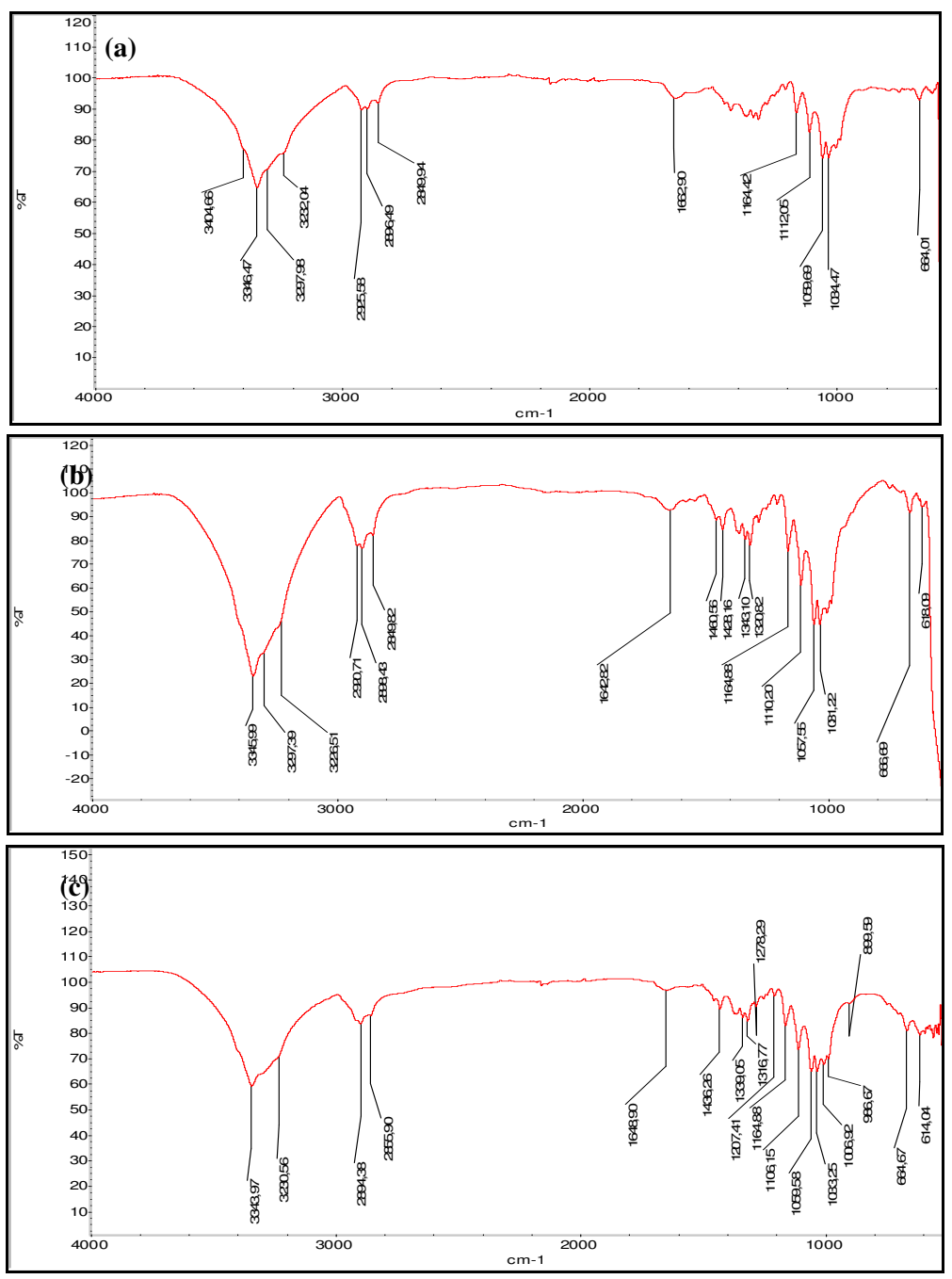

Figure 6: FTIR spectra of bacterial cellulose obtained from different media; (a) Hestrin-Schramm;

(b) Tilia cordata; (c) Rosa canina

The thermal behavior of the obtained BC pellicles was also determined by TGA. The thermograms of $\mathrm{BC}$ originated from $R$. canina, $T$. cordata and HS media revealed three phases of degradation (Fig. 7). Accordingly, the initial weight loss is observed from $30{ }^{\circ} \mathrm{C}$ to $\sim 200{ }^{\circ} \mathrm{C}$ for R. canina ( $7.5 \%$ weight loss), from $30{ }^{\circ} \mathrm{C}$ to $\sim 250$ ${ }^{\circ} \mathrm{C}$ for $T$. cordata (7.5\% weight loss) and from 30 ${ }^{\circ} \mathrm{C}$ to $\sim 240{ }^{\circ} \mathrm{C}$ for HS media (5\% weight loss) corresponded to the evaporation of the adsorbed surface water from $\mathrm{BC}$ pellicle. ${ }^{3,33}$ The second weight loss is detected from $\sim 230{ }^{\circ} \mathrm{C}$ to $350{ }^{\circ} \mathrm{C}$
(67.5\% weight loss) for $R$. canina, from $\sim 250{ }^{\circ} \mathrm{C}$ to $390{ }^{\circ} \mathrm{C}$ for $T$. cordata ( $82.5 \%$ weight loss) and $\sim 240{ }^{\circ} \mathrm{C}$ to $320{ }^{\circ} \mathrm{C}$ for HS media $(29 \%$ weight loss), and this stage is attributed to thermal degradation, including depolymerization, dehydration and decomposition of cellulose pellicles. ${ }^{55,67}$ In the last stage, the third weight loss is determined $\sim 350{ }^{\circ} \mathrm{C}$ to $580{ }^{\circ} \mathrm{C}(10 \%$ weight loss) for $R$. canina, $\sim 390{ }^{\circ} \mathrm{C}$ to $630{ }^{\circ} \mathrm{C}(15 \%$ weight loss) for $T$. cordata and $\sim 340{ }^{\circ} \mathrm{C}$ to $660{ }^{\circ} \mathrm{C}$ (41\% weight loss) for HS media, corresponding to the volatilization and oxidation of char. ${ }^{41}$ 
Accordingly, total weight losses were found as $85 \%, 97.5 \%$ and $75 \%$ for the cellulose obtained from $R$. canina, $T$. cordata and HS media, respectively (Fig. 7). To sum up, it was observed that the thermal behavior of $\mathrm{BC}$ may vary depending on the source used for its production. Also, all of the $\mathrm{BC}$ pellicles obtained in this research show high thermal stability.
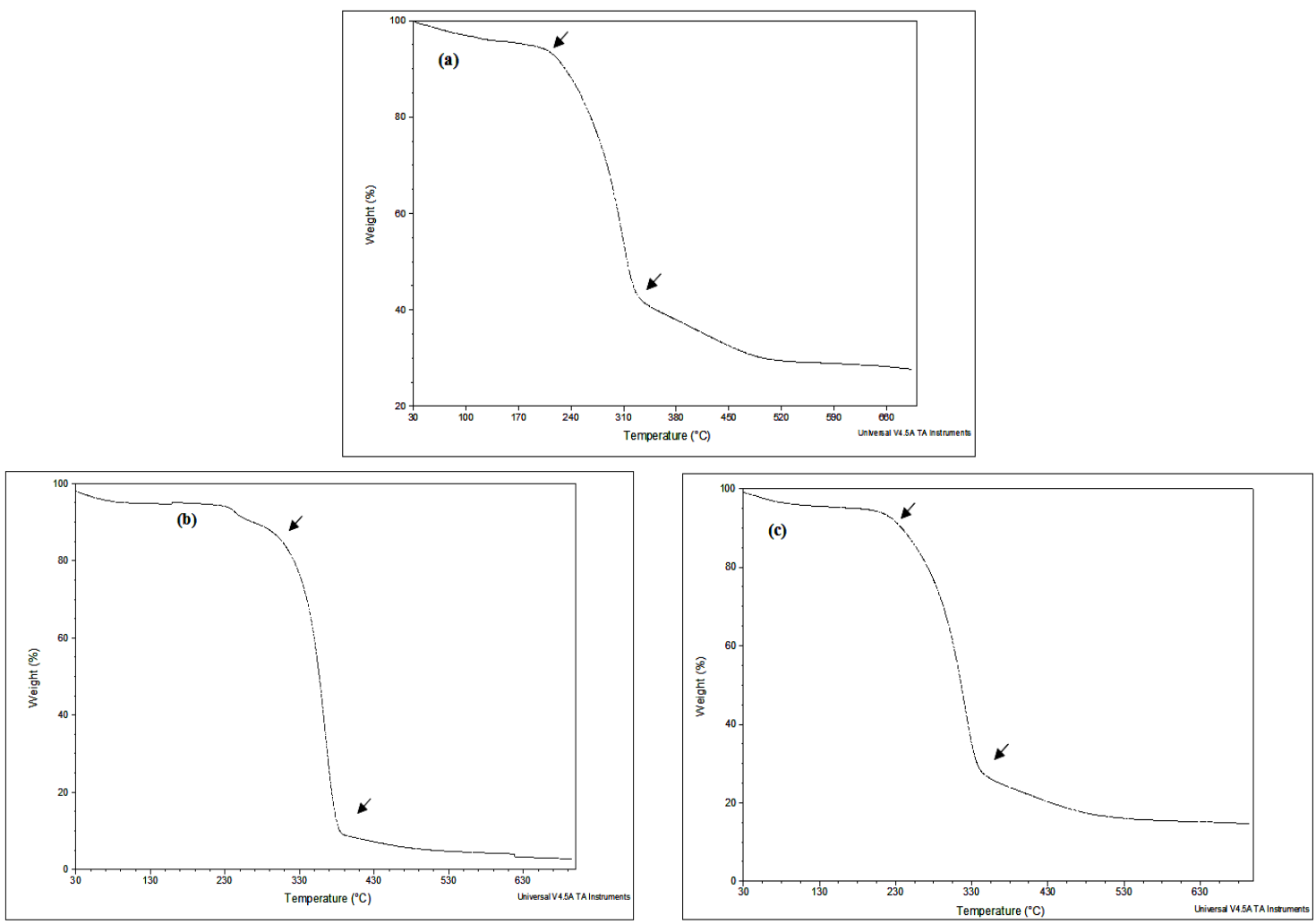

Figure 7: Thermogravimetric analysis of bacterial cellulose obtained from different media;

(a) Hestrin-Schramm media; (b) Tilia cordata; (c) Rosa canina

\section{CONCLUSION}

This study investigated the effects of low-cost substrates, namely $L$. angustifolia, $R$. canina and $T$. cordata plants, in cellulose production by Komagataeibacter intermedius strain. Under optimal conditions, $5.42 \mathrm{~g} / \mathrm{L} \mathrm{BC}, 8.5 \mathrm{~g} / \mathrm{L} \mathrm{BC}$ and $10.64 \mathrm{~g} / \mathrm{L} \mathrm{BC}$ were produced with $L$. angustifolia, $R$. canina and $T$. cordata plants, respectively. Also, it has been found that the phenolic and protein contents of the plants contribute significantly to cellulose formation in the production medium, which does not contain any carbon source and extra substrate other than the plant itself. The amounts of cellulose pellicles obtained from $T$. cordata and $R$. canina plants were 1.6 and 1.25 times higher than that from Hestrin-Schramm medium (6.6 g/L BC). Additionally, the plant wastes were re-used 10 times and $4.11 \mathrm{~g} / \mathrm{L}$ and $2.36 \mathrm{~g} / \mathrm{L} \mathrm{BC}$ production was observed on the $10^{\text {th }}$ brew of $R$. canina and $T$. cordata, respectively. According to the results of SEM, FTIR and TGA analyses, it was observed that the BC achieved from these plants showed randomly organized nanofibrils, has high thermal stability and all the peaks obtained from FTIR analysis are characteristic of BC. Therefore, it was determined that $\mathrm{BC}$ can be successfully produced using $K$. intermedius strain, and $T$. cordata and $R$. canina plants can be used as alternative plant-based media to produce BC with high purity through an eco-friendly process. On the basis of the obtained results, it was established that the use of L. angustifolia, R. canina and $T$. cordata plants contributes to cost-effective and highly efficient $\mathrm{BC}$ production.

ACKNOWLEDGEMENT: This research did not receive any specific grant from funding agencies of the public, commercial, or not-for-profit sectors. 


\section{REFERENCES}

F. Cakar, I. Özer, A. Ö. Aytekin and F. Şahin, Carbohyd. Polym., 106, 7 (2014), https://doi.org/10.1016/j.carbpol.2014.01.103. 2014

2 S. S. Wang, Y. H. Han, J. L. Chen, D. C. Zhang, X. X. Shi et al., Polymers, 10, 963 (2018), https://doi.org/10.3390/polym10090963

3 R. F. Dorame-Miranda, N. Gamez-Meza, L. A. Medina-Juarez, J. M. Ezquerra-Brauer, M. OvandoMartínez et al., Carbohyd. Polym., 207, 91 (2019), https://doi.org/10.1016/j.carbpol.2018.11.067

4 K. Aswini, N. O. Gopal and S. Uthandi, $B M C$ Biotechnol., 20, 46 (2020)

5 J. Fernandez, A. G. Morena, S. V. Valenzuela, F. J. Pastor, P. Díaz et al., J. Polym. Environ., 27, 956 (2019), https://doi.org/10.1007/s10924-019-01403-4

6 H. Biyik and E. Poyrazoglu Coban, Eur. J. Biotechnol. Biosci., 5, 74 (2017)

7 P. Semjonovs, M. Ruklisha, L. Paegle, M. Saka, R. Treimane et al., Biotechnol. Prod. Process Eng., 101, 1003 (2017), https://doi.org/10.1007/s00253-0167761-8

8 A. Vazquez, M. L. Foresti, P. Cerrutti and M. Galvagno, J. Polym. Environ., 21, 545 (2013), https://doi.org/10.1007/s10924-012-0541-3

9 S. M. Yim, J. E. Song and H. R. Kim, Process $\begin{array}{llll}\text { Biochem., } & \text { 59, } & 26 & \text { (2017), }\end{array}$ https://doi.org/10.1016/j.procbio.2016.07.001

10 A. Suwanposri, P. Yukphan, Y. Yamada and D. Ochaikul, Maejo International Journal of Science and Technology, 8, 1 (2014)

11 M. U. Islam, M. W. Ullah, S. Khan, N. Shah and J. K. Park, Int. J. Biol. Macromol., 102, 1166 (2017), https://doi.org/10.1016/j.ijbiomac.2017.04.110

12 V. Kumar, D. K. Sharma, V. Bansal, D. Mehta, R. S. Sangwan et al., Bioresour. Technol., 275, 430 (2019), https://doi.org/10.1016/j.biortech.2018.12.042

13 H. Zhao, J. Xia, J. Wang, X. Yan, C. Wang et al., Biotehnol. Biotechnol. Equip., 32, 350 (2018), https://doi.org/10.1080/13102818.2017.1418673

14 V. Revin, E. Liyaskina, M. Nazarkina, A. Bogatyreva and M. Shchankin, Brazil. J. Microbiol., 49, $151 \quad$ (2018), https://doi.org/10.1016/j.bjm.2017.12.012

15 C. Sharma and N. K. Bhardwaj, Int. J. Biol. Macromol., $\quad$ 132, $166 \quad$ (2019), https://doi.org/10.1016/j.ijbiomac.2019.03.202

16 F. Mohammadkazemi, M. Azin and A. Ashori, Carbohyd. Polym., 117, 518 (2015), https://doi.org/10.1016/j.carbpol.2014.10.008

${ }_{17}$ M. A. S. Keshk, J. Bioprocess. Biotech., 4, $1000150 \quad$ (2014), https://doi.org/10.4172/21559821.1000150

18 G. Gopu and S. Govindan, Prep. Biochem. Biotechnol., 48, 842 (2018)

19 B. Hungund, S. Prabhu, C. Shetty, S. Acharya, V. Prabhu et al., J. Microb. Biochem. Technol., 5, 31 (2013), https://doi.org/10.4172/1948-5948.1000095
20 A. F. Jozala, L. C. de Lencastre-Novaes, A. M. Lopes, V. C. Santos-Ebinuma, P. G. Mazzola et al., Appl. Microbiol. Biotechnol., 100, 2063 (2016), https://doi.org/10.1007/s00253-015-7243-4

21 E. J. Al-Kalifawi and I. A. Hassan, Baghdad Sci. J., 11, 1420 (2014)

22 B. V. Mohite, B. K. Salunke and S. V. Patil, Appl.

Biochem. Biotechnol., 169, $1497 \quad$ (2013), https://doi.org/10.1007/s12010-013-0092-7

${ }^{23}$ H. Khan, A. Kadam and D. Dutt, Carbohyd. Polym., 229, $115513 \quad$ (2020), https://doi.org/10.1016/j.carbpol.2019.115513

${ }_{24}$ F. P. Gomes, N. H. C. S. Silva, E. Trovatti, L. S. Serafim, M. F. Duarte et al., Biomass Bioenerg., 55, 205 (2013), https://doi.org/10.1016/j.biombioe.2013.02.004. 2013

${ }_{25}$ R. Du, F. Zhao, Q. Peng, Z. Zhou and Y. Han, Carbohyd. Polym., 194, $200 \quad$ (2018), https://doi.org/10.1016/j.carbpol.2018.04.041

26 W. Soemphol, P. Hongsachart and V. Tanamool, Mater. Today-Proc., $\quad$ 5, $11159 \quad$ (2018), https://doi.org/10.1016/j.matpr.2018.01.036

27 B. C. Adebayo-Tayo, M. O. Akintunde and S. O. Alao, Turkish J. Agric. Nat. Sci., 4, 145 (2017)

28 E. A. Hassan, H. M. Abdelhady, S. S. Abd ElSalam and S. M. Abdulah, British Microbiol. Res. J., 9, 1 (2015), https://doi.org/10.9734/BMRJ/2015/18223

29 M. Güzel and O. Akpinar, Waste Biomass Valorif., 10, 2165 (2019), https://doi.org/10.1007/s12649-0180241

${ }^{30}$ K. V. Ramana and H. V. Batra, Appl. Biochem. Biotechnol., $\quad$ 176, $1162 \quad$ (2015), https://doi.org/10.1007/s12010-015-1637-8

31 S. A. Villarreal-Soto, S. Beaufort, J. Bouajila, J. P. Souchard, T. Renard et al., Process Biochem., 83, 44 (2019), https://doi.org/10.1016/j.procbio.2019.05.004

32 G. Pacheco, C. R. Nogueira, A. B. Meneguin, E. Trovatti, M. C. C. Silva et al., Ind. Crop. Prod., 107, 13

https://doi.org/10.1016/j.indcrop.2017.05.026

33 N. Phruksaphithak, C. Kaewnun and O. Sompong, Science, Engineering and Health Studies, 13, 1 (2019), https://doi.org/10.14456/sehs.2019.1

34 E. A. Skiba, V. V. Budaeva, E. V. Ovchinnikova, E. K. Gladysheva, E. I. Kashcheyeva et al., Chem. Eng. J., 383, $123128 \quad$ (2020), https://doi.org/10.1016/j.cej.2019.123128

35 Y. Raiszadeh-Jahromi, M. Rezazadeh-Bari, H. Almasi and S. Amiri, J. Food Sci. Technol., 57, 2524 (2020), https://doi.org/10.1007/s13197-020-04289-6

36 H. Azeredo, H. Barud, C. S. Farinas, V. M. Vasconcellos and A. M. Claro, Front. Sustain. Food $\begin{array}{llll}\text { Syst., } & \mathbf{3}, & 7 & \text { (2019), }\end{array}$ https://doi.org/10.3389/fsufs.2019.00007.2019

37 X. Fan, Y. Gao, W. He, H. Hu, M. Tian et al., Carbohyd. Polym., 151, 1068 (2016), https://doi.org/10.1016/j.carbpol.2016.06.062 
38 S. M. Keshk, T. M. A. Razek and K. Sameshima, Afr. J. Biotechnol., 5, $1519 \quad$ (2006), https://doi.org/10.4314/ajb.v5i17.43149

39 N. Tyagi and S. Suresh, J. Clean. Prod., 112, 71 (2016), https://doi.org/10.1016/j.jclepro.2015.07.054

40 E. Tsouko, C. Kourmentza, D. Ladakis, N. Kopsahelis, I. Mandala et al., Int. J. Mol. Sci., 16, 14832 (2015), https://doi.org/10.3390/ijms160714832

41 J. Ye, S. Zheng, Z. Zhang, F. Yang, K. Ma et al., Bioresour. Technol., 274, $518 \quad$ (2019), https://doi.org/10.1016/j.biortech.2018.12.028

42 F. Jahan, V. Kumar and R. K. Saxena, Bioresour. Technol., $\quad$ 250, $\quad 922 \quad$ (2018), https://doi.org/10.1016/j.biortech.2017.09.094

43 X. Zeng, D. P. Small and W. Wan, Carbohyd. Polym., $\quad$ 85, $506 \quad$ (2011), https://doi.org/10.1016/j.carbpol.2011.02.034

44 O. H. Lowry, N. J. Rosebrough, A. L. Farr and R. J. Randall, J. Biol. Chem., 193, 265 (1951), https://doi.org/10.1016/S0021-9258(19)52451-6

45 G. L. Miller, Anal. Chem., 31, 426 (1959)

46 V. L. Singleton and A. R. Joseph, American Journal of Enology and Viticulture, 16, 144 (1965)

47 E. P. Çoban and H. Biyik, Afr. J. Biotechnol., 10, 5346 (2011), https://doi.org/10.5897/AJB10.1693

48 C. Molina-Ramirez, M. Castro, M. Osorio, M. Torres-Taborda, B. Gomez et al., Materials, 10, 639 (2017), https:doi.org/10.3390/ma10060639

49 X. He, H. Meng, H. Song, S. Deng, T. He et al., Carbohyd. Res., 493, $108030 \quad$ (2020), https://doi.org/10.1016/j.carres.2020.108030

50 C. Castro, R. Zuluaga, C. Alvarez, J. L. Putaux, G. Caro et al., Carbohyd. Polym., 89, 1033 (2012), https://doi.org/10.1016/j.carbpol.2012.03.045

51 S. C. Duda, L. A. Mărghitaş, D. Dezmirean, M. Duda, R. Mărgăoan et al., Ind. Crop. Prod., 77, 499 (2015), https://doi.org/10.1016/j.indcrop.2015.09.045

52 J. D. Nađpal, M. M. Lesjak, F. S. Šibul, G. T. Anačkov, D. D. Četojević-Simin et al., Food Chem., 192 , 907

(2016),
53 O. Sytar, I. Hemmerich, M. Zivcak, C. Rauh and M. Brestic, Saudi J. Biol. Sci., 25, 631 (2018), https://doi.org/10.1016/j.sjbs.2016.01.036

54 G. L. Chen, S. G. Chen, Y. Q. Xie, F. Chen, Y. Y. Zhao et al., J. Funct. Foods, 17, 243 (2015), https://doi.org/10.1016/j.jff.2015.05.028

55 M. Elmastaş, A. Demir, N. Genç, Ü. Dölek and M. Güneş, Food Chem., 235, 154 (2017), https://doi.org/10.1016/j.foodchem.2017.05.004

56 M. Tabaszewska and D. Najgebauer-Lejko, NFS J., 21, 50

(2020),

https://doi.org/10.1016/j.nfs.2020.09.003

57 H. L. S. Lima, E. S. Nascimento, F. K. Andrade, A. I. S. Brigida, M. F. Borges et al., Braz. J. Chem. Eng., 34, 671 (2017), https://doi.org/10.1590/01046632.20170343s20150514

58 A. Kurosumi, C. Sasaki, Y. Yamashita and Y. Nakamura, Carbohyd. Polym., 76, 333 (2009), https://doi.org/10.1016/j.carbpol.2008.11.009

59 B. E. Rangaswamy, K. P. Vanitha and B. S. Hungund, Int. J. Polym. Sci., 2015, 280784 (2015), http://dx.doi.org/10.1155/2015/280784

60 N. H. Avcioglu, M. Birben and I. S. Bilkay, Process Biochem., 108, 60 (2021), https://doi.org/10.1016/j.procbio.2021.06.005.2021

61 S. Bandyopadhyay, N. Saha and P. Saha, Appl. Biochem. Microbiol., 54, 649 (2018)

62 N. A. Yanti, S. W. Ahmad, N. H. Muhiddin, L. O. A. N. Ramadhan and T. Walhidayah, Pak. J. Biol. Sci., 24, 335

(2021),

https://doi.org/10.3923/pjbs.2021.335.344

63 D. Abol-Fotouh, M. A. Hassan, H. Shokry, A. Roig, M. S. Azab et al., Sci. Rep., 10, 1 (2020), https://doi.org/10.1038/s41598-020-60315-9

${ }_{64}$ S. P. Lin, Y. H. Huang, K. D. Hsu, Y. J. Lai, Y. K. Chen et al., Carbohyd. Polym., 151, 827 (2016), https://doi.org/10.1016/j.carbpol.2016.06.032

65 H. Khan, V. Saroha, S. Raghuvanshi, A. K. Bharti and D. Dutt, Carbohyd. Polym., 260, 117807 (2021), https://doi.org/10.1016/j.carbpol.2021.117807

66 S. O. Dima, D. M. Panaitescu, C. Orban, M. Ghiurea, S. M. Doncea et al., Polymers, 9, 374 (2017), https://doi.org/10.3390/polym9080374 